\begin{tabular}{|l|l|l||}
\hline \multicolumn{2}{|c|}{ PublisherInfo } \\
\hline \hline PublisherName & $:$ & BioMed Central \\
\hline \hline PublisherLocation & $:$ & London \\
\hline \hline PublisherImprintName & $:$ & BioMed Central \\
\hline \hline
\end{tabular}

\title{
Tamoxifen may reduce CHD risk via inflammatory mediators
}

\begin{tabular}{|l|l|l||}
\hline \multicolumn{2}{|c|}{ ArticleInfo } \\
\hline \hline ArticleID & $:$ & 47 \\
\hline \hline ArticleDOI & $:$ & $10.1186 / c v m-2001-72051$ \\
\hline \hline ArticleCitationID & $:$ & 72051 \\
\hline \hline ArticleSequenceNumber & $:$ & 26 \\
\hline \hline ArticleCategory & $:$ & Paper Report \\
\hline \hline ArticleFirstPage & $:$ & 1 \\
\hline \hline ArticleLastPage & $:$ & 3 \\
\hline \hline & & $\mid$ RegistrationDate $: 2001-10-18$ \\
ArticleHistory & $:$ & Received \\
\hline \hline ArticleCopyright & $:$ & Biomed Central Ltd2001 \\
\hline \hline ArticleGrants & $:$ & \\
\hline \hline
\end{tabular}




\begin{tabular}{|l|l|l|}
\hline ArticleContext & $:$ & 1306322 \\
\hline
\end{tabular}

Joanna Lyford, Aff1

Corresponding Affiliation: Aff1

Aff1 MedWire, UK

Keywords

Breast cancer, cardiovascular disease, cholesterol, C-reactive protein, fibrinogen, tamoxifen

\section{Context}

Previous breast cancer trials have demonstrated reductions in cardiac death of between $15 \%$ and $60 \%$ in women treated with tamoxifen. This study investigated whether tamoxifen reduces the levels of inflammatory markers that are linked to an increased risk of heart disease.

\section{Significant findings}

Tamoxifen was shown to reduce levels of C-reactive protein by $26 \%$ and fibrinogen levels by $22 \%$, as well as a $9 \%$ reduction in cholesterol. All of these reductions were significant compared with the effects of placebo $(P<0.01)$. Specific treatment effects were not noted with factor VII coagulant, fragment 1-2, and triglycerides.

\section{Comments}

The authors suggested that a proinflammatory effect of hormone replacement therapy might relate to an increased risk of myocardial infarction shortly after beginning therapy. Differences in the effects of tamoxifen, raloxifene, and estrogen on inflammation markers may prove to have clinical implications for the use of these agents in women at increased cardiovascular risk. The authors noted that, although the epidemiologic evidence relating C-reactive protein and fibrinogen to vascular disease risk is compelling, a cause-effect relationship is not proven. Tamoxifen's lowering effect on these factors might 
relate either to altered production or degradation. Any clinical consequence of this is unknown. A larger study is now warranted.

\section{Methods}

The authors studied 111 women previously enrolled in the National Surgical Adjuvant Breast and Bowel Program P-1 trial. The average age of the women was 58 years and most were postmenopausal. Fifty-one women were randomly assigned to receive tamoxifen $20 \mathrm{mg} /$ day and the remainder took placebo. The study period was 6 months.

\section{Additional information}

\section{References}

1. Cushman M, Costantino JP, Tracy RP, Song K, Buckley L, Roberts JD, Krag DN: Tamoxifen and cardiac risk factors in healthy women: suggestion of an anti-inflammatory effect. Arterioscler Thromb Vasc Biol. 2001, 21: 225-261. 